\title{
Adsorptive Removal of Heavy Metals from Aqueous Solution with Environmental Friendly Material-Exhausted Tea Leaves
}

\author{
Bindra Shrestha $^{1 *}$, Jagjit Kour ${ }^{1}$, Kedar Nath Ghimire ${ }^{2}$ \\ ${ }^{1}$ Department of Chemistry, Tri-Chandra Campus, Kathmandu, Nepal \\ ${ }^{2}$ Central Department of Chemistry, Tribhuvan University, Kirtipur, Nepal \\ Email: ^binraghu@yahoo.com
}

How to cite this paper: Shrestha, B., Kour, J. and Ghimire, K.N. (2016) Adsorptive Removal of Heavy Metals from Aqueous Solution with Environmental Friendly Material-Exhausted Tea Leaves. Advances in Chemical Engineering and Science, 6, 525-540. http://dx.doi.org/10.4236/aces.2016.64046

Received: September 5, 2016

Accepted: October 24, 2016

Published: October 27, 2016

Copyright $\odot 2016$ by authors and Scientific Research Publishing Inc. This work is licensed under the Creative Commons Attribution International License (CC BY 4.0).

http://creativecommons.org/licenses/by/4.0/

\begin{abstract}
In this study adsorptive removal of $\mathrm{Pb}$ (II) and $\mathrm{Cu}$ (II) from aqueous solution by using environmental friendly natural polymers present in exhausted tea leaves has been studied. The biosorbent was modified with dimethylamine to introduce $\mathrm{N}$-functional groups on the surface of adsorbent. The modified adsorbent was characterized by elemental analysis, zeta potential analysis, SEM, DRFTIR, XRD and TG/DTA analysis to conform the modification. Adsorption capacity of the adsorbent was determined as the function of $\mathrm{pH}$ of the solution, initial concentration of the solution and contact time. The adsorption experiments were performed using batch experiments. The maximum adsorption capacities of the adsorbent were found to be 91.68 and $71.20 \mathrm{mg} / \mathrm{g}$ for $\mathrm{Pb}(\mathrm{II})$ and $\mathrm{Cu}(\mathrm{II})$, respectively. To minimize the process cost, regeneration of the biosorbent and recovery of metal ions was explored by desorption study. The results indicate that the adsorbent holds great potential for the sequestration of $\mathrm{Pb}$ (II) and $\mathrm{Cu}$ (II) from their aqueous solution. Hence the modified exhausted tea leaves (MTL) have been investigated as a new cost effective and efficient biosorbent for removal of $\mathrm{Pb}(\mathrm{II})$ and $\mathrm{Cu}(\mathrm{II})$ from their aqueous solution.
\end{abstract}

\section{Keywords}

Natural Polymer, Biosorbent, Heavy Metals, Dimethylamine, Exhausted Tea Leaves

\section{Introduction}

The rapid industrial development causes environmental contamination with heavy metals. The industries like electroplating, alloy formation, leather tanning, textiles, dye, and mining discharge a large amount of heavy metal contaminated waste water to the 
aquatic environment. As heavy metals are non-biodegradable and soluble in aquatic environment, they are absorbed by living organisms. Once they enter the food chain they tend to accumulate in living organisms causing serious health disorders [1]. Lead is one of the most toxic environmental pollutants which cause health hazards even in trace concentration. Copper is one of the most important heavy metals used in electroplating and brass manufacture. Compounds of copper are used in agriculture. It deposits in skin, brain, liver, pancreas and myocardium causing serious toxicity [2]. Therefore the metal contaminated waste water must be treated prior to their discharge to the environment.

The conventional methods to remove heavy metals include chemical precipitation, oxidation reduction, electrochemical treatment, ion exchange, co-precipitation and membrane filtration. These processes become inefficient and expensive when the metals are present only in trace concentration, in order of $1-100 \mathrm{mg} / \mathrm{L}$ [3]. For such solution the adsorption by activated carbon is more effective for metal removal. But the method becomes highly expensive for treatment of waste water [4]. In such case biosorption provides an attractive alternative to the conventional methods [5]. The advantages of biosorption include their cost effectiveness, high efficiency and minimization of sludge production, regeneration of biosorbent and possibility of metal recovery [6].

Biosorbents are prepared from naturally abundant waste biomass. They contain different types of functional groups on their surface including carboxylate, hydroxyl, amine, amide and phosphate which are found to be responsible for metal sorption. But the sorption capacities of native biosorbents have been reported unsatisfactory with low sorption capacity [7].

The surface modification of biomass increases the sorption capacity. The common chemical modification methods are acid or alkali treatment, crosslinking with glutaraldehyde, epichlorohydrin [8] [9]. Similarly the surface of the biosorbent can be chemically modified to introduce more effective functional groups like $\mathrm{N}$-functional groups (amino, hydrazine, amide and imidazoline groups), phosphate group, and xanthate group [10]-[12]. It is obvious that the metal sorption capacity increases after the introduction of a large number of effective groups on the surface of the biosorbent. The $\mathrm{N}$ atoms of functional groups would have a greater tendency to donate a pair of electrons for sharing with metal ions to form metal complexes [13]. It has been reported that adsorbents with $\mathrm{N}$-functional groups favor the metal ion adsorption through the chelation mechanism. Such $\mathrm{N}$-functional groups on the surface of biosorbent have been found to be more effective chelating group for adsorption of heavy metals from aqueous solution [14]. Hence there has been considerable interest in surface modification to introduce $\mathrm{N}$-functional groups so as to enhance the adsorption capability of biosorbent.

Many researchers have been used various biosorbents in less effective way [15]-[18]. In present study exhausted tea leaves-a biowaste, have been used as biosorbent. After water tea is the most widely consumed beverage in the world. The tea leaves (Camellia sinensis), once the beverage has been brewed become a waste. The exhausted tea leaves were then chemically modified to introduce $\mathrm{N}$-functional group. The modified biosor- 
bent was characterized using spectral and elemental analysis. The adsorption behaviors including effect of $\mathrm{pH}$, sorption isotherm and kinetics of adsorption were investigated for the adsorption of $\mathrm{Pb}(\mathrm{II})$ and $\mathrm{Cu}(\mathrm{II})$ from their aqueous solution.

\section{Materials and Methods}

\subsection{Adsorbent, Chemicals, Reagents and Instrumentations}

The exhausted tea leaves (ETL) were washed with hot distilled water for several times till the filtrate became clear. After thorough washing, it was dried in an oven at $80^{\circ} \mathrm{C}$ for $24 \mathrm{hrs}$. The dried biosorbent was powdered and sieved to pass through the $212 \mu \mathrm{m}$ sieve. About $100 \mathrm{~g}$ of the powdered sample was treated with acid which removes the water soluble substances and the polymeric network of the adsorbent is also exposed for further treatment. The acid treated tea leaves was washed several times with distilled water till neutrality and dried in an oven at $80^{\circ} \mathrm{C}$ for $24 \mathrm{hrs}$. The adsorbent was then aminated with dimethylamine. The procedures used are similar to those earlier reported [19]. The prepared sample was called Modified tea leaves (MTL).

The biosorbent was characterized by elemental analysis (Elementar Vario Macro elemental analysis instrument-Italy), SEM images (S-3000 N Scanning Electron Microscope of HITACHI, Japan), DRFTIR spectra (Harrick scientific corporation-Italy), XRD (X-Ray diffractometer, Rigaku-Japan), TG/DTA analysis (TG (/DTA 6200-Japan).

To prepare $\mathrm{Pb}(\mathrm{II})$ and $\mathrm{Cu}(\mathrm{II})$ solutions, their Stock solutions of $1000 \mathrm{mg} / \mathrm{L}$ were prepared by dissolving calculated amount of lead nitrate and copper sulphate in $0.1 \mathrm{M}$ $\mathrm{HNO}_{3}$. Working solutions of various concentrations were prepared by diluting the stock solution with $0.1 \mathrm{M} \mathrm{HNO}_{3}$. In all the experimental works $\mathrm{pH}$ of the solutions were maintained by using $0.1 \mathrm{M} \mathrm{HNO}_{3}$ and $0.1 \mathrm{M} \mathrm{NaOH}$. For $\mathrm{pH}$ measurement Hanna Instrument was used. The 0.1 M solution of 2-[4-(2-hydroxymethyl)-1-piperazinyl] ethanesulphonic acid [HEPES] was used as buffer. All the chemicals used were of analytical grade (AR) and double distilled water was used wherever necessary for the experimental works. During the experiments the concentration of metal ions were analyzed using Atomic Absorption Spectroscopy (Agilent technologies, AAS, model-240FSAA, USA).

\subsection{Adsorption Experiments}

\subsubsection{Effect of $\mathrm{pH}$}

The adsorption capacity of the adsorbent was studied as the function of $\mathrm{pH}$ keeping the concentration of metal ions constant by using batch experiment. $20 \mathrm{~mL}$ of $50 \mathrm{mg} / \mathrm{L}$ metal solutions with $\mathrm{pH} 1$ to 7 were added to $50 \mathrm{~mL}$ conical flasks, each with $25 \mathrm{mg}$ adsorbent. The flasks were shaken for $24 \mathrm{hrs}$ in a mechanical shaker at $150 \mathrm{rpm}$ maintaining the temperature at $25^{\circ} \mathrm{C}$. After shaking, the mixtures were filtered. The $\mathrm{pH}$ of filtrates was measured and concentration of metal ions was analyzed using AAS. The adsorption efficiency, $\mathrm{A} \%$ can be calculated by using following equation

$$
A \%=\frac{C_{i}-C_{e}}{C_{i}} \times 100
$$


where $C_{i}$ is initial concentration and $C_{e}$ is equilibrium concentration of metal ions.

\subsubsection{Isotherm Study}

Isotherms of adsorption were determined by taking $20 \mathrm{~mL}$ of metal solutions of various concentrations ranging from 25 to $800 \mathrm{mg} / \mathrm{L}$ in conical flasks containing $25 \mathrm{mg}$ of adsorbent in each. The optimum $\mathrm{pH}$ of the solutions was maintained using $0.1 \mathrm{M} \mathrm{NaOH}$ and $0.1 \mathrm{M} \mathrm{HNO}_{3}$. The flasks were shaken for $24 \mathrm{hrs}$ in a mechanical shaker at $150 \mathrm{rpm}$. After shaking the mixtures were filtered and the residual concentration of respective metal ions was analyzed in AAS.

\subsubsection{Kinetic Study}

To determine the optimum time for the adsorption, $20 \mathrm{~mL}$ of $50 \mathrm{mg} / \mathrm{L}$ solutions were taken in several conical flasks containing $25 \mathrm{mg}$ of adsorbent in each. The optimum $\mathrm{pH}$ of solutions was maintained by adding $0.1 \mathrm{M} \mathrm{NaOH}$ and $0.1 \mathrm{M} \mathrm{HNO}_{3}$. The flasks were shaken in a mechanical shaker at $50 \mathrm{rpm}$. The flasks were taken out from the shaker after each predetermined intervals of time and filtered. The filtrates were analyzed for concentration of metal ions in AAS.

\section{Results and Discussion}

\subsection{Characterization}

To enhance the adsorption capacity of the biosorbent, it was chemically modified with dimethylamine. During the chemical modification it is supposed that the alcoholic and phenolic $\mathrm{OH}$ groups present in lignin, cellulose and hemicelluloses of the biosorbent were substituted with $\mathrm{N}$-functional group. The introduction of $\mathrm{N}$-functional groups is indicated by the elemental analysis of the adsorbent before and after modification. The percentage of nitrogen in tea leaves is 1.03 , which is increased to 5.5 after modification. The modified biosorbent was further characterized by Scanning electron microscope (SEM), Diffused reflectance fourier transform infrared spectroscopy (DRFTIR), X-ray diffraction analysis (XRD) and Thermogravimetric analysis (TG/DTA).

\subsubsection{Scanning Electron Microscope (SEM) Analysis}

The surface morphology of the biosorbent was examined by its SEM images. The images are given in Figure 1. Initially the surface of the exhausted tea leaves is found smooth with uniform micro porous structure which becomes rough after modification indicating the chemical modification of the adsorbent. The surface of tea leaves after modification shows irregularly distributed pores, which are supposed to be formed due to the increase of effective diffusion surface area derived from pore formation [20]. The enhancement of metal sorption after modification may be due to the rough surface of MTL with pores [21].

\subsubsection{Diffused Reflectance Fourier Transform Infrared Spectroscopy (DRFTIR)} In this experiment, acid treated biosorbent was modified by using dimethylamine. Introduction of this N-functional group can be analysed by infrared spectroscopy. In 

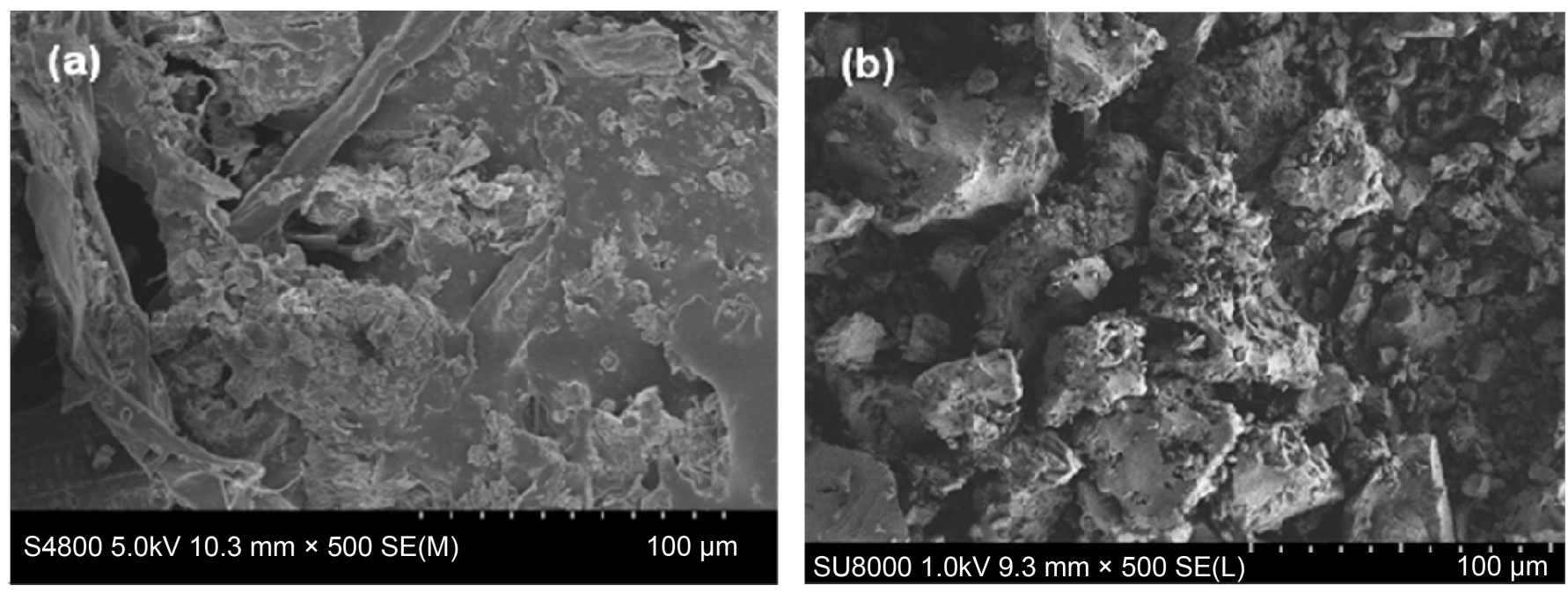

Figure 1. SEM images (a) and (b) of ETL and MTL, respectively.

DRFTIR analysis, each specific chemical bond often shows a unique energy absorption band and it has been used as a useful tool to identify the presence of certain functional groups on the surface of the biosorbent [22] [23].

The DRFTIR spectra of ETL and MTL are shown in Figure 2. The spectra are complex due to numerous different types of functional groups on the surface of adsorbent. In the spectrum of ETL, the peaks can be assigned as follows, $3388 \mathrm{~cm}^{-1}$ was due to $\mathrm{OH}$ stretching, $2924 \mathrm{~cm}^{-1}$ due to $\mathrm{CH}$ stretching in $\mathrm{CH}, \mathrm{CH}_{2}$ and $\mathrm{CH}_{3}$ groups, $1646 \mathrm{~cm}^{-1}$ due to $\mathrm{C}=\mathrm{O}$ stretching in carbonyl group and $1078 \mathrm{~cm}^{-1}$ due to $\mathrm{C}-\mathrm{O}$ stretching. After chemical modification the spectrum exhibits some significant changes. The broad band ranging from about 3118 to $3650 \mathrm{~cm}^{-1}$ corresponds to the combination of stretching vibration bands of both $\mathrm{OH}$ and $\mathrm{NH}$ groups suggesting that $\mathrm{N}$-functional groups are introduced on the surface of the biosorbent. The peaks at $1450 \mathrm{~cm}^{-1}$ and $1033 \mathrm{~cm}^{-1}$ are due to the $\mathrm{C}-\mathrm{H}$ bending and $\mathrm{C}-\mathrm{N}$ stretching, respectively.

\subsubsection{X-Ray Diffraction Analysis (XRD)}

$\mathrm{X}$-ray diffraction profiles of exhausted tea leaves and modified tea leaves are shown in Figure 3.

In the profile there are broad peaks with strongest reflection at $2 \theta$ around $22^{\circ}$. The MTL shows less intense and broader peak than ETL which corresponds to the less crystalline structure. The increasing amorphous nature of biosorbent is highly suitable for metal adsorption.

\subsubsection{Thermogravimetric Analysis (TG/DTA)}

The thermal stability and degradation behavior of the biosorbents were evaluated by TGA under nitrogen atmosphere using a thermal analyser with increase in temperature of $10 \mathrm{~min}^{-1}$. The TGA and DTA curves for the adsorbents are shown in Figure 4 .

The raw material degraded mainly in two stages. The first stage of decomposition started at around $260^{\circ} \mathrm{C}$ and finally at $450^{\circ} \mathrm{C}$. The first stage corresponds to decomposition of lignocellulosic materials and the second corresponds to complete decomposition. 


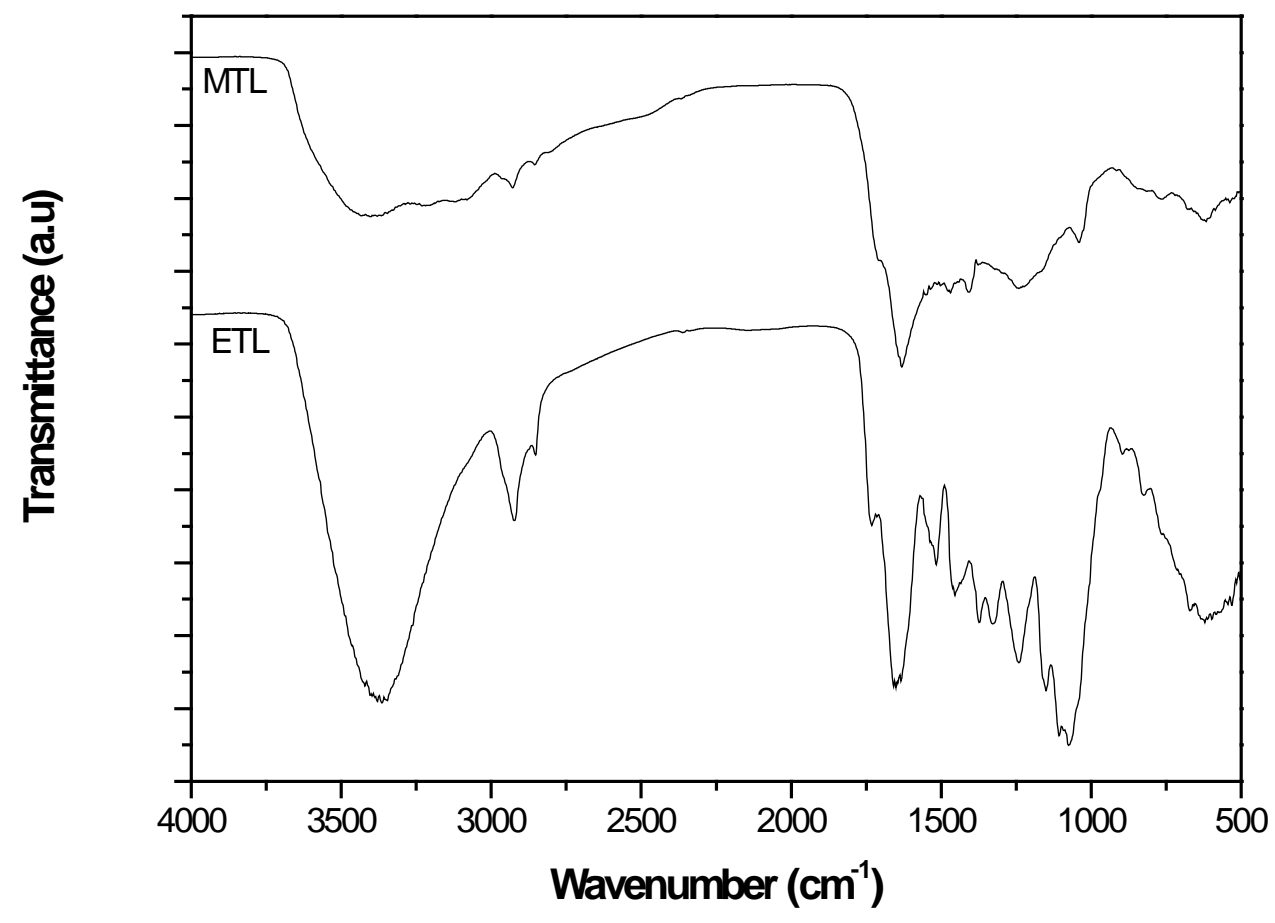

Figure 2. Drftir spectra of ETL and MTL.

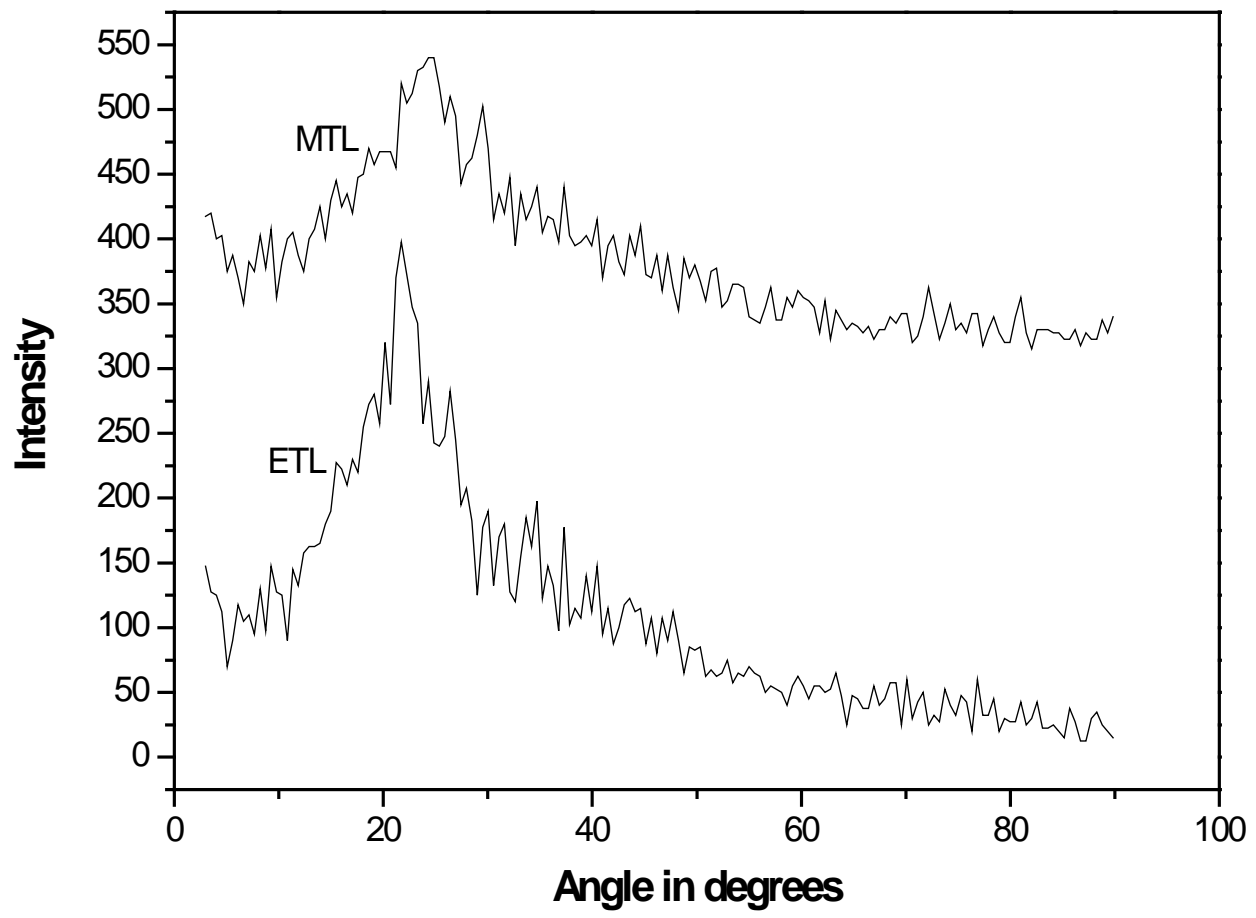

Figure 3. XRD profile of ETL and MTL.

Similarly in modified adsorbent the first stage degradation begins at about $100^{\circ} \mathrm{C}$ with weight loss of $5 \%-10 \%$. It is due to loss of residual or physically adsorbed water molecules. The second stage degradation occurs with rapid weight loss at $300^{\circ} \mathrm{C}-560^{\circ} \mathrm{C}$ 


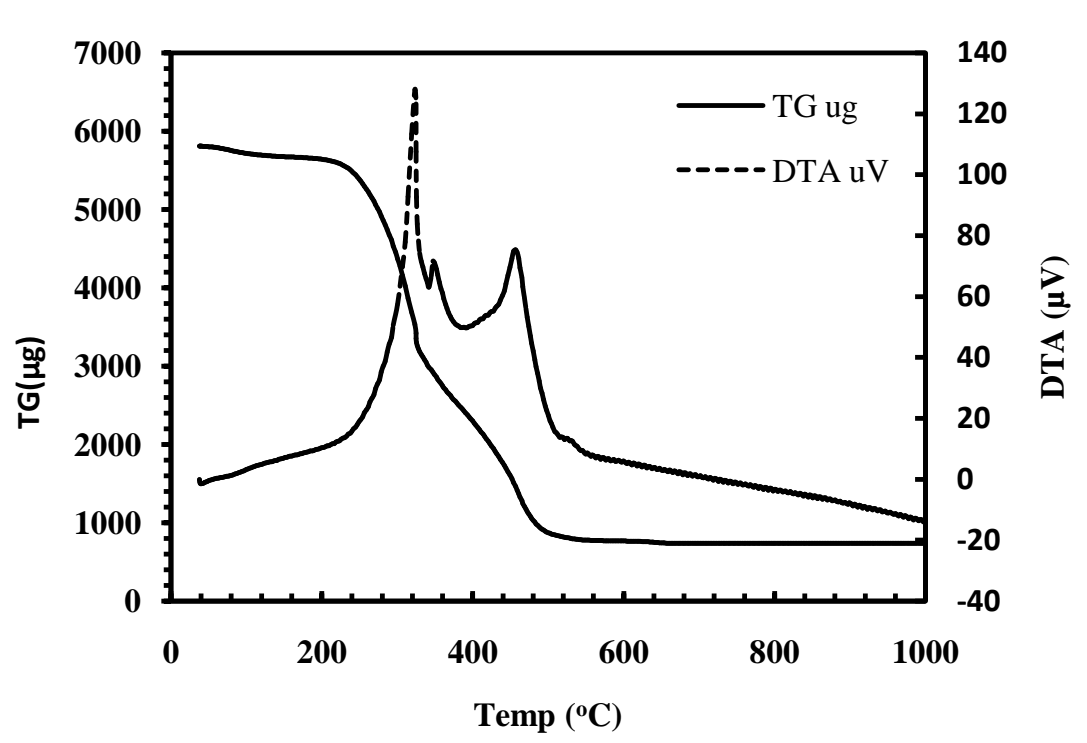

(a)

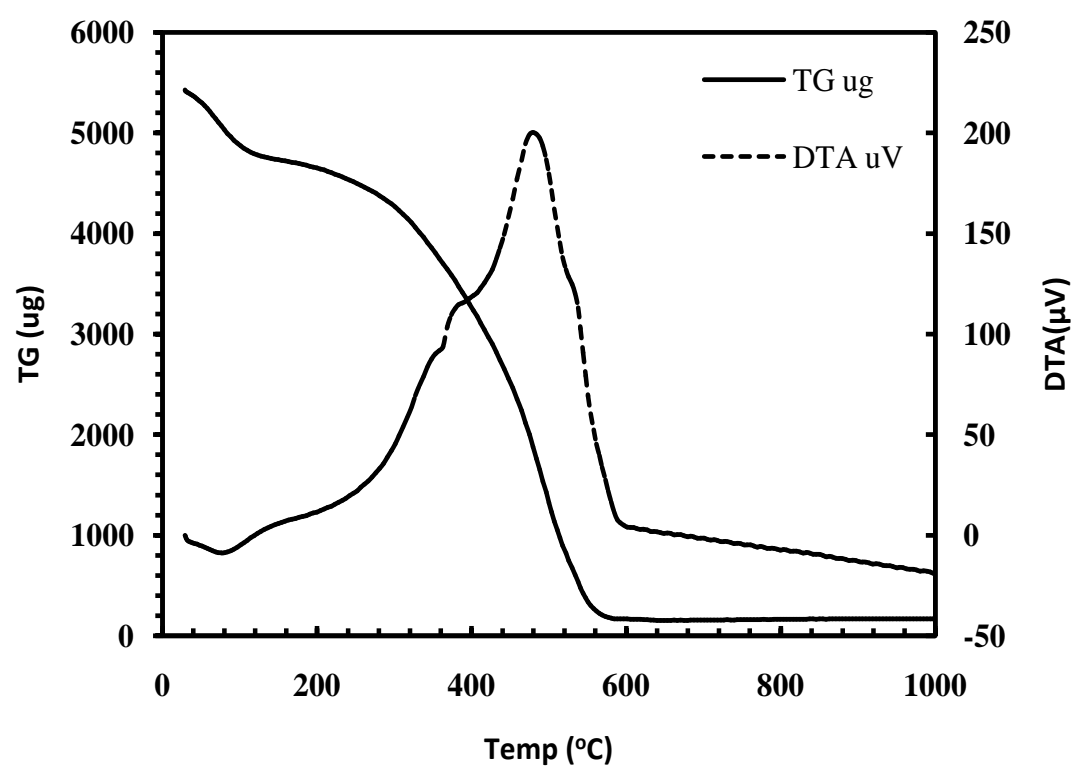

(b)

Figure 4. TG/DTA analysis (a) and (b) of ETL and MTL, respectively.

reaching a maximum value at $485^{\circ} \mathrm{C}$. It indicates the increasing thermal stability of the biosorbent after modification.

\subsection{Adsorption Characters}

\subsubsection{Effect of $\mathrm{pH}$}

The percentage adsorption of $\mathrm{Pb}$ (II) and $\mathrm{Cu}$ (II) as the function of equilibrium $\mathrm{pH}$ are shown in Figure 5. The plot shows that the adsorption of metal ions increases with increase of $\mathrm{pH}$. The optimum $\mathrm{pH}$ for uptake of $\mathrm{Pb}$ (II) and $\mathrm{Cu}$ (II) onto MTL were found to be at 4 and 5 , respectively. The adsorption increases rapidly near the optimum $\mathrm{pH}$ range. 


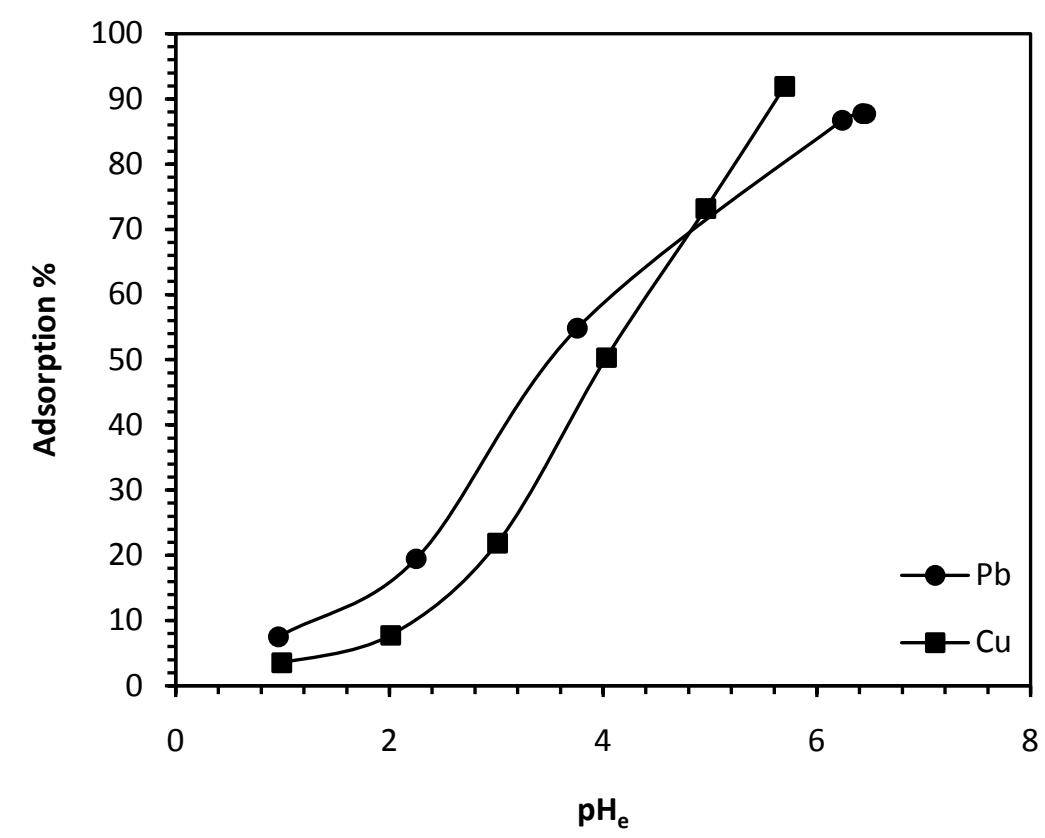

Figure 5. Adsorption of $\mathrm{Pb}(\mathrm{II})$ and $\mathrm{Cu}(\mathrm{II})$ onto $\mathrm{MTL}$ as the function of equilibrium pH. Adsorbent dose $25 \mathrm{mg}$, vol. of metal solution $20 \mathrm{~mL}$ and initial metal concentration $50 \mathrm{~mL} / \mathrm{L}$.

As the surface charge of the adsorbent changes with $\mathrm{pH}$ of solution and degree of ionization as well as the adsorbate species also depends upon solution $\mathrm{pH}$, the adsorptive removal of metal ions depends upon the $\mathrm{pH}$ of the solution [24] [25]. The increase of sorption capacity with increase of $\mathrm{pH}$ of the solution can be explained on the basis of surface charge of the adsorbent and the degree of ionization. At low $\mathrm{pH}$, highly mobile $\mathrm{H}^{+}$would compete with metal ions for the active binding sites. Hence at low $\mathrm{pH}$ all the binding sites may be protonated which tends to decrease the metal sorption on the surface of the adsorbent. At higher $\mathrm{pH}$, concentration of $\mathrm{H}^{+}$as well as solubility of metals decrease which enhance the metal sorption on the surface of the adsorbent. Further increase in $\mathrm{pH}$ causes precipitation of metals as their hydroxide.

The $\mathrm{pH}_{\mathrm{pzc}}$ of an adsorbent is a very important characteristic that determines the $\mathrm{pH}$ at which the adsorbent surface has net electrical neutrality. The zeta potential of the ETL and MTL in the solution of different $\mathrm{pH}$ values are shown in Figure 6.

The zeta potentials of ETL are positive at $\mathrm{pH}<5.9$ and negative at $\mathrm{pH}>5.9$. After modification, the zeta potentials of MTL are negative at $\mathrm{pH}>10$ and positive at $\mathrm{pH}<$ 10. It indicates that the point of zero zeta potential for the ETL at 5.9 was changed to that for MTL around 10, due to surface modification [26]. The higher point of zero zeta potential for the adsorbent after modification may be due to protonation of $\mathrm{N}$-atoms in the amine group introduced on the surface of the adsorbent.

\subsubsection{Adsorption Isotherm}

The study of adsorption isotherm evaluates the adsorption capacity of the adsorbent. Adsorption capacity is the concentration of metal ions on the adsorbent and can be 


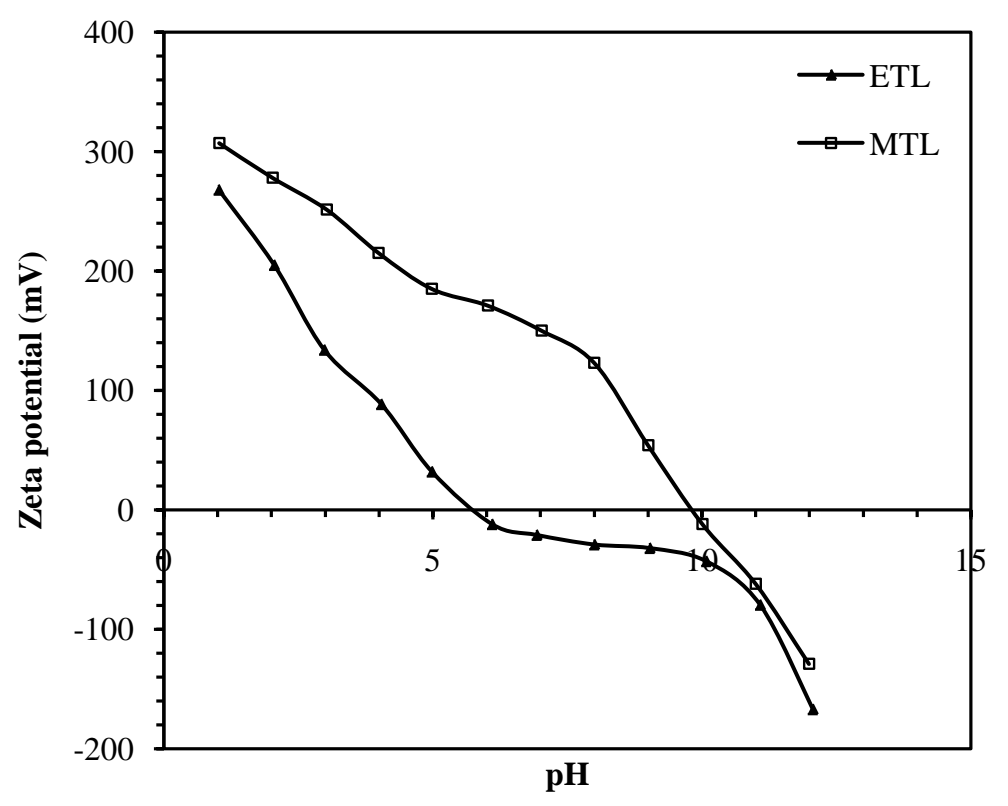

Figure 6. Zeta potentials of the ETL and MTL as the function of solution pH values.

calculated on the basis of mass balance principle as follows

$$
q=\frac{C_{i}-C_{e}}{W} \times \frac{L}{1000}
$$

where $q$ is the amount of metal adsorbed per unit mass of the adsorbent, $\mathrm{L}$ is volume of metal solution, $\mathrm{W}$ is dry mass of the adsorbent and $C_{i}$ and $C_{e}$ are initial and final concentration of metal ions, respectively.

Langmuir adsorption isotherm has been widely used for many adsorption processes. The basic assumption of Langmuir adsorption theory is that the driving force of adsorption is concentration of metal ions in solution and the bare binding sites available on the surface of adsorbent. The adsorption takes place at specific binding sites available on the surface of the adsorbent and once the site is occupied by metal ions no further sorption can occur. Figure 7 shows the adsorption isotherms for $\mathrm{Pb}$ (II) and $\mathrm{Cu}$ (II) onto MTL.

In the plot, initially the adsorption of metal ions increases with increase in equilibrium concentration of metal ions. Eventually the uptake of metal ions is limited by the occupied binding sites and results in a plateau. It showed that the active sites of the adsorbent remaining constant, the adsorption are independent of the concentration of metal ions at high concentration of metal ions [27] [28]. The maximum adsorption capacities from the experimental results are 91.68 and $71.2 \mathrm{mg} / \mathrm{g}$ for $\mathrm{Pb}(\mathrm{II})$ and $\mathrm{Cu}(\mathrm{II})$, respectively.

The adsorption isotherms were evaluated using linearized Langmuir model by using Equation (3)

$$
\frac{C_{e}}{q_{e}}=\frac{1}{q_{m} b}+\frac{C_{e}}{q_{m}}
$$




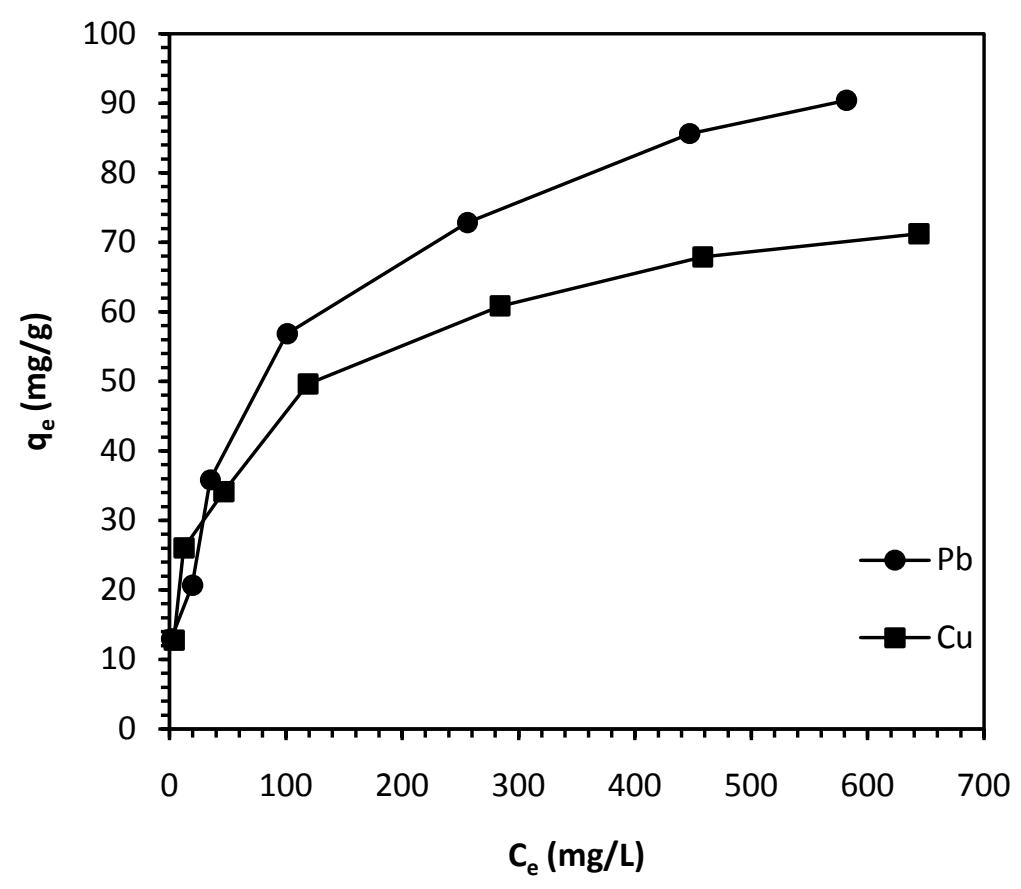

Figure 7. Effect of concentration on adsorption of $\mathrm{Pb}$ (II) and $\mathrm{Cu}$ (II) onto MTL. Adsorbent dose $25 \mathrm{mg}$, vol. of metal solution $20 \mathrm{~mL}$ at $\mathrm{pH}=4$ and 5 for respective metal ions.

where $q_{e}$ is amount adsorbed $(\mathrm{mg} / \mathrm{g}), C_{e}$ is equilibrium concentration of metal ions $(\mathrm{mg} / \mathrm{L}), q_{m}(\mathrm{mg} / \mathrm{g})$ is the maximum adsorption capacity and $b(\mathrm{~L} / \mathrm{mg})$ is the binding constant. The linear plot of $C_{e} / q_{e}$ verses $C_{e}$ as shown in Figure 8 suggests the applicability of Langmuir adsorption isotherm and indicates the formation of monolayer coverage of metal ions on the surface of adsorbent. Langmuir parameters $q_{m}$ and $b$ were calculated from the slop and intercept of the plot. The values are given in Table 1 along with correlation coefficient $\mathrm{R}^{2}$.

The higher $\mathrm{R}^{2}$ values confirm the best fitting of Langmuir isotherm model. The comparable theoretical maximum adsorption capacity based on Langmuir adsorption equation with the experimental values suggests that the adsorbent can be used for effective sequestration of $\mathrm{Pb}(\mathrm{II})$ and $\mathrm{Cu}(\mathrm{II})$ from their aqueous solution.

\subsubsection{Kinetics of Adsorption}

The study of adsorption kinetics helps to evaluate the efficiency of adsorption. The effect of contact time on adsorption of $\mathrm{Pb}(\mathrm{II})$ and $\mathrm{Cu}(\mathrm{II})$ onto MTL is shown in Figure 9.

The plot consists of initial rapid phase where the rate of adsorption is fast. This rapid phase is related to external surface adsorption and occurs instantaneously. The initial high rate is due to the existence of the bare surface for metal binding. There is a slower second phase which is a gradual adsorption stage and equilibrium uptake was achieved. In this phase the adsorption of metal ions is limited due to the occupied surface of the adsorbent. The time to reach equilibrium is $100-150 \mathrm{~min}$ for the metal ions.

To describe the kinetics of adsorption, pseudo-second order kinetic model is applied 


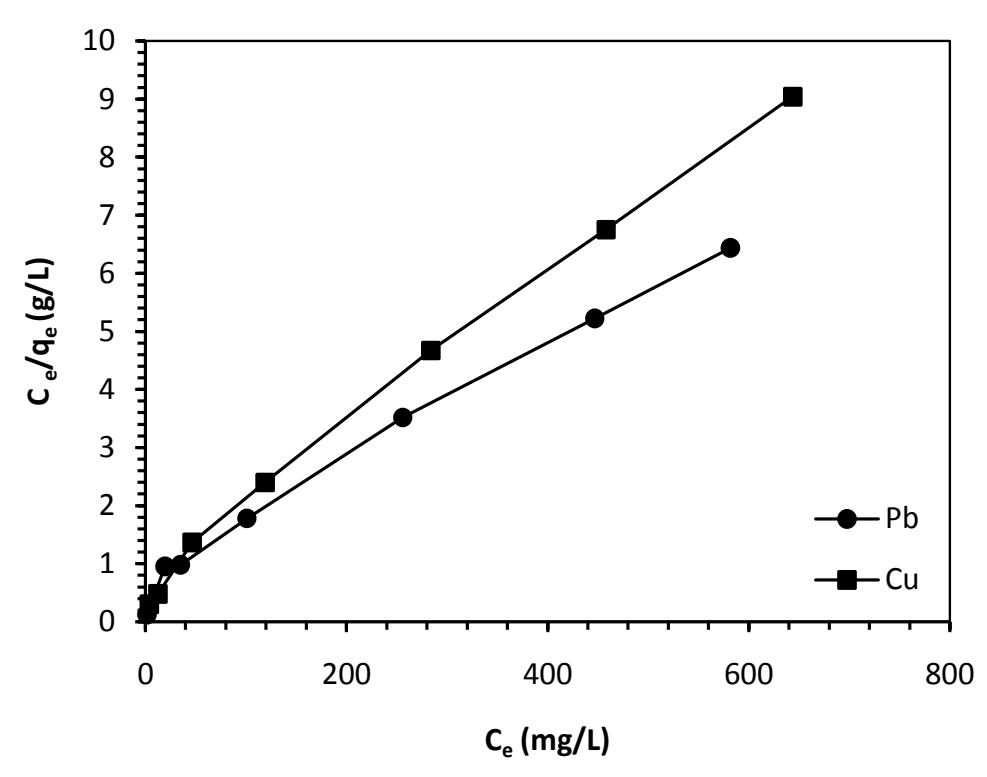

Figure 8. Langmuir isotherm for adsorption of $\mathrm{Pb}(\mathrm{II})$ and $\mathrm{Cu}$ (II) onto MTL.

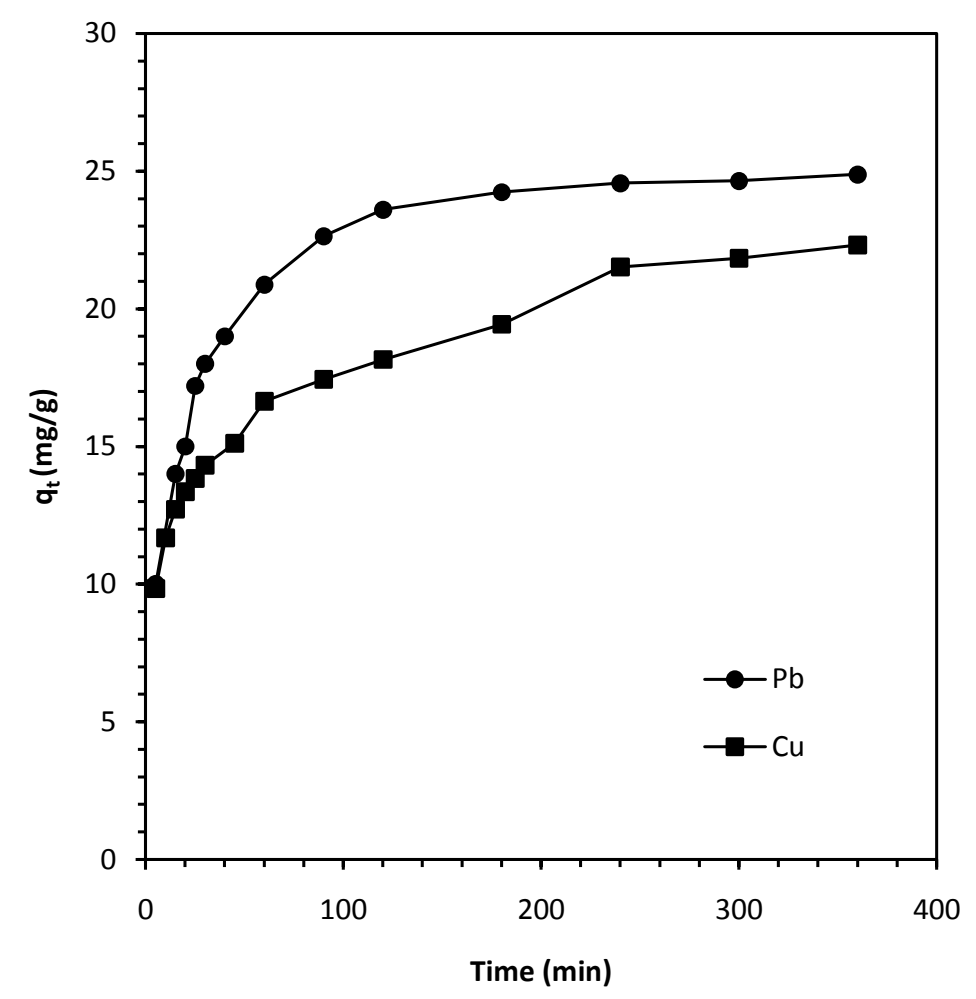

Figure 9. Adsorption kinetics of $\mathrm{Pb}(\mathrm{II})$ and $\mathrm{Cu}(\mathrm{II})$ onto MTL. Adsorbent dose $25 \mathrm{mg}$, vol. of metal solution $20 \mathrm{~mL}$ at $\mathrm{pH}=4$ and 5 for respective metal ions.

[29]. The model can be expressed as

$$
\frac{t}{q_{t}}=\frac{1}{K_{2} q_{e}^{2}}+\frac{t}{q_{e}}
$$


Table 1. Langmuir adsorption isotherm model parameters and experimental $\mathrm{q}_{\max }$.

\begin{tabular}{ccccc}
\hline Metal ions & $\begin{array}{c}q_{m}(\text { expt. }) \\
(\mathrm{mg} / \mathrm{g})\end{array}$ & $\begin{array}{c}q_{m}(\mathrm{graph}) \\
(\mathrm{mg} / \mathrm{g})\end{array}$ & $\mathrm{b} \mathrm{L} / \mathrm{mg})$ & $\mathrm{R}^{2}$ \\
\hline $\mathrm{Pb}(\mathrm{II})$ & 91.68 & 98.04 & 0.017 & 0.993 \\
$\mathrm{Cu}(\mathrm{II})$ & 71.20 & 74.07 & 0.024 & 0.995 \\
\hline
\end{tabular}

where $q_{t}$ is the amount of metal ions adsorbed at time $\mathrm{t}(\mathrm{min})$ and $\mathrm{K}_{2}(\mathrm{~g} / \mathrm{mg} / \mathrm{min})$ is the rate constant of pseudo-second order kinetics of adsorption. The plot of $t / q_{t}$ verses $t$ is a straight line as shown in Figure 10.

The plot with high $\mathrm{R}^{2}$ values as given in Table 2, indicates the applicability of pseudo-second order model and chemisorptions of the adsorption of $\mathrm{Pb}(\mathrm{II})$ and $\mathrm{Cu}(\mathrm{II})$.

\subsubsection{Comparison of the Adsorption Capacities}

The metal adsorption capacity of MTL was compared with other biosorbents described in the literature. The different capabilities are due to presence of different functional groups on the surface of adsorbent. The values are given in Table 3. From the table MTL is found as an efficient biosorbent with higher metal binding capacity.

\subsubsection{Desorption}

For the use of cost effective biosorption process as an alternative in the waste water treatment scheme, the regeneration of biosorbent becomes crucially important for keeping the process cost down. For this purpose the adsorbed metals should be desorbed from the biosorbent and regenerated for another cycle of application [30]. After desorption, the metals can be recovered by extraction from the liquid phase.

In this experiment $0.1 \mathrm{~g}$ of the adsorbent was used for adsorption of lead at $100 \mathrm{ml} / \mathrm{L}$ in $80 \mathrm{ml}$ of solution for $6 \mathrm{hrs}$. The adsorbent was regenerated with $0.1 \mathrm{M} \mathrm{HNO}_{3}$ and rinsed with double distilled water. After drying at $80^{\circ} \mathrm{C}$ for $24 \mathrm{hrs}$, the adsorbent was used in subsequent adsorption experiment. In the first sorption cycle the adsorption capacity was found to be $58 \mathrm{mg} / \mathrm{g}$ for $\mathrm{Pb}$ (II) which was decreased to $56.40 \mathrm{mg} / \mathrm{g}$ in second cycle. Then the value remains almost constant for other successive adsorption-desorption cycles. It is observed that the regenerated adsorbent maintained high metal uptake capacity for lead. The metal desorbed by $0.1 \mathrm{M} \mathrm{HNO}_{3}$ from the adsorbent was found to be above $91 \%$ which remained almost constant over six cycles. It also indicates the chemical stability of adsorbent after modification. During the desorption experiments, the loss in dry weight of the adsorbent was less than $10 \%$.

\section{Conclusions}

A new and efficient biosorbent has been investigated successfully by chemical modification of exhausted tea leaves. The surface of biosorbent was modified by introduction of $\mathrm{N}$-functional groups using dimethylamine. The adsorbent was characterized by elemental analysis, SEM, DRFTIR, XRD and TG/DTA analysis. The optimum $\mathrm{pH}$ was found to be 4 and 5 for $\mathrm{Pb}(\mathrm{II})$ and $\mathrm{Cu}(\mathrm{II})$, respectively. The study of isotherms was well 


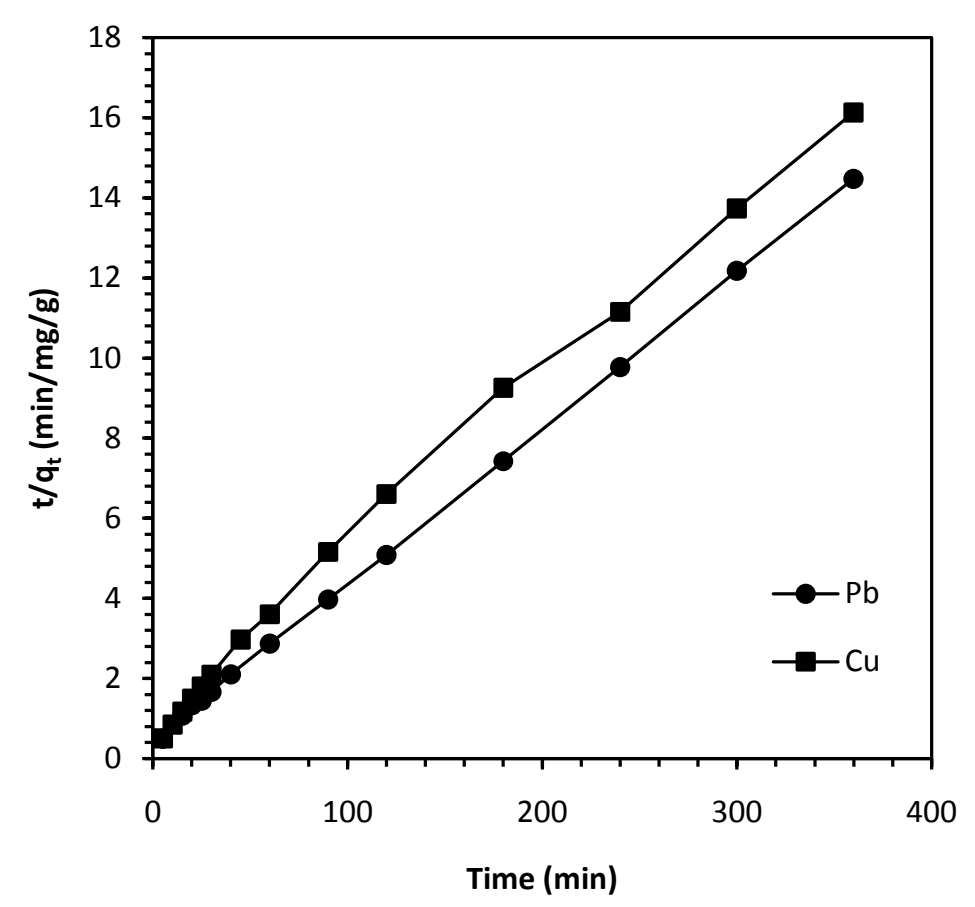

Figure 10. Pseudo-second order kinetic model for adsorption of $\mathrm{Pb}(\mathrm{II})$ and $\mathrm{Cu}(\mathrm{II})$ onto MTL.

Table 2. Pseudo-second order kinetics for adsorption of $\mathrm{Pb}(\mathrm{II})$ and $\mathrm{Cu}(\mathrm{II})$ onto MTL.

\begin{tabular}{cccc}
\hline Metal ions & $q_{e}(\mathrm{mg} / \mathrm{g})$ & $\mathrm{K}_{2}(\mathrm{~g} / \mathrm{mg} / \mathrm{min})$ & $\mathrm{R}^{2}$ \\
\hline $\mathrm{Pb}(\mathrm{II})$ & 25.71 & 0.003 & 0.999 \\
$\mathrm{Cu}(\mathrm{II})$ & 22.88 & 0.002 & 0.996 \\
\hline
\end{tabular}

Table 3. Comparision of adsorption capacities ( $\mathrm{mg} / \mathrm{g}$ ) of different biosorbents for the removal of metal ions reported in the literatures.

\begin{tabular}{cccc}
\hline Adsorbents & $\mathrm{Pb}(\mathrm{II})$ & $\mathrm{Cu}(\mathrm{II})$ & References \\
\hline Modified tea leaves (MTL) & 91.68 & 71.2 & This study \\
Peanut husk & 29.41 & - & {$[31]$} \\
Alfalfa biomass & 89.2 & - & {$[32]$} \\
Nipah palmshoot biomass & - & 66.71 & {$[33]$} \\
Azolla filiculoides & - & 62 & {$[34]$} \\
\hline
\end{tabular}

fitted with Langmuir model. The metal adsorption process was found to follow pseudosecond order kinetic model with higher $\mathrm{R}^{2}$ values. The maximum sorption capacities for $\mathrm{Pb}(\mathrm{II})$ and $\mathrm{Cu}(\mathrm{II})$ were found to be 91.68 and $71.2 \mathrm{mg} / \mathrm{g}$, respectively. After adsorption the biosorbent was successfully regenerated by $0.1 \mathrm{HNO}_{3}$. The regenerated biosorbent can be used repeatedly for metal adsorption. These experimental results revealed that MTL can be used as an efficient biosorbent for the sequestration of $\mathrm{Pb}$ (II) and $\mathrm{Cu}(\mathrm{II})$ from their aqueous solution. 


\section{Acknowledgements}

Authors gratefully acknowledge National Institute of Material Science (NIMS), Japan, for providing lab facility to carry out this research work.

\section{References}

[1] Babel, S. and Kurniawan, T.A. (2003) Low Cost Adsorbents for Heavy Metals Uptake from Contaminated Water: A Review. Journal of Hazardous Materials, B97, 219-243. http://dx.doi.org/10.1016/S0304-3894(02)00263-7

[2] Nurchi, V.M. and Villaescusa, I. (2008) Agricultural Biomasses as Sorbents of Some Trace Metals. Coordination Chemistry Review, 252, 1178-1188. http://dx.doi.org/10.1016/j.ccr.2007.09.023

[3] Sun, G. and Shi, W. (1998) Sunflower Stalks as Adsorbents for the Removal of Metal Ions from Wastewater. Industrial \& Engineering Chemistry Research, 37, 1324-1328. http://dx.doi.org/10.1021/ie970468j

[4] Igwe, J.C. and Abia, A.A. (2006) A Bioseparation Process for Removing Heavy Metals from Wastewater Using Biosorbents-Review. African Journal of Biotechnology, 5, 1167-1179.

[5] Volesky, B. and Holan, Z.R. (1995) Biosorption of Heavy Metals. Biotechnology Progress, 11, 235-250. http://dx.doi.org/10.1021/bp00033a001

[6] Das, N., Vimala, R. and Karthika, P. (2008) Biosorption of Heavy Metals-An Overview. Indian Journal of Biotechnology, 7, 159-169.

[7] Wan Ngah, W.S. and Hanafiah, M.A.K.M. (2008) Removal of Heavy Metal Ions from Wastewater by Chemically Modified Plant Wastes as Adsorbents: A Review. Bioresource Technology, 99, 3935-3948. http://dx.doi.org/10.1016/j.biortech.2007.06.011

[8] Ghimire, K.N., Inoue, K., Ohto, K. and Hayashida, T. (2007) Adsorptive Separation of Metallic Pollutants onto Waste Seaweeds, Porphyra yezoensis and Ulva japonica. Separation Science and Technology, 42, 2003-2018. http://dx.doi.org/10.1080/15363830701313461

[9] Biswas, B.K., Inoue, K., Ghimire, K.N., Harada, H., Ohto, K. and Kawakita, H. (2008) Removal and Recovery of Phosphorus from Water by Means of Adsorption onto Orange Waste Gel Loaded with Zirconium. Bioresource Technology, 99, 8685-8690. http://dx.doi.org/10.1016/j.biortech.2008.04.015

[10] Deng, S., Bai, R. and Chen, J.P. (2003) Aminated Polyacrylonitrile Fibers for Lead and Copper Removal. Langmuir, 19, 5058-5064. http://dx.doi.org/10.1021/la034061x

[11] Kour, J., Homagai, P.L., Cagnin, N., Masi, A., Pokhrel, M.R. and Ghimire, K.N. (2013) Adsorption of $\mathrm{Cd}(\mathrm{II}), \mathrm{Cu}(\mathrm{II})$, and $\mathrm{Zn}(\mathrm{II})$ from Aqueous Solution onto Nitrogen-Functionalized Desmostachya bipinnata. Journal of Chemistry, 2013, Article ID: 649142. http://dx.doi.org/10.1155/2013/649142

[12] Homagai, P.L., Ghimire, K.N. and Inoue, K. (2011) Preparation and Characterization of Charred Xanthated Sugarcane Bagasse for the Separation of Heavy Metals from Aqueous Solutions. Separation Science and Technology, 46, 330-339. http://dx.doi.org/10.1080/01496395.2010.506903

[13] Nietoa, L.M., Alamia, S.B.D., Hodaifab, G., Faurc, C., Rodrigueza, S., Gimeneza, J.A. and Ochandoa, J. (2010) Adsorption of Iron on Crude Olive Stones. Industrial Crops and Products, 32, 467-471. http://dx.doi.org/10.1016/j.indcrop.2010.06.017

[14] Demirbas, A. (2008) Heavy Metal Adsorption onto Agrobased Waste Materials: A Review. Journal of Hazardous Materials, 157, 220-229. http://dx.doi.org/10.1016/j.jhazmat.2008.01.024 
[15] Mahvi, A.H., Naghipour, D., Vaezi, F. and Nazmara, S. (2005) Teawaste as an Adsorbent for Heavy Metal Removal from Industrial Wastewaters. American Journal of Applied Sciences, 2, 372. http://dx.doi.org/10.3844/ajassp.2005.372.375

[16] Chen, S., Yue, Q., Gao, B. and Xu, X. (2010) Equilibrium and Kinetic Adsorption Study of the Adsorptive Removal of Cr (VI) Using Modified Wheat Residue. Journal of Colloid and Interface Science, 349, 256-264. http://dx.doi.org/10.1016/j.jcis.2010.05.057

[17] Amarasinghe, B.M.W.P.K. and Williams, R.A. (2007) Tea Waste as a Low Cost Adsorbent for the Removal of $\mathrm{Cu}$ and $\mathrm{Pb}$ from Wastewater. Chemical Engineering Journal, 132, 299309. http://dx.doi.org/10.1016/j.cej.2007.01.016

[18] Islam, T.A., Begum, H.A., Hossain, M.A. and Rahman, M.T. (2009) Removal of Pb(II) from Aqueous Solution by Sorption on Used Tea Leaves. Journal of Bangladesh Academy of Sciences, 33, 167-178.

[19] Shrestha, B., Homagai, P.L., Pokhrel, M.R. and Ghimire, K.N. (2012) Adsorptive Removal of Toxic Metal from Aqueous Solution by Using a Biowaste Used Tea Leaves. Nepal Journal of Science and Technology, 13, 109-114.

[20] Sankaramakrishnan, N. and Sanghi, R. (2006) Preparation and Characterization of a Novel Xanthated Chitosan. Carbohydrate Polymers, 6, 160-167. http://dx.doi.org/10.1016/j.carbpol.2006.02.035

[21] Moussavi, G. and Khosravi, R. (2010) Removal of Cyanide from Wastewater by Adsorption onto Pistachio Hull Wastes: Parametric Experiments, Kinetics and Equilibrium Analysis. Journal of Hazardous Materials, 183, 724-730. http://dx.doi.org/10.1016/j.jhazmat.2010.07.086

[22] Shriner, R.L., Hermann, C.K.F., Morill, T.C., Curtin, D.Y. and Fuson, R.C. (1998) The Systematic Identification of Organic Compounds. 7th Edition, Wiley, New York.

[23] Pavasant, P., Apiratikul, R., Sungkhum, V., Suthiparinyanont, P., Wattanachira, S. and Marhaba, T.F. (2006) Biosorption of $\mathrm{Cu}^{2+}, \mathrm{Cd}^{2+}, \mathrm{Pb}^{2+}$ and $\mathrm{Zn}^{2+}$ Using Dried Marine Green Macroalga Caulerpa lentillifera. Bioresource Technology, 97, 2321-2329. http://dx.doi.org/10.1016/j.biortech.2005.10.032

[24] Ayyappan, R., Sophia, A.C., Swaminathan, K. and Shandhya, S. (2005) Removal of Pb(II) from Aqueous Solution Using Carbon Derived from Agricultural Wastes. Process Biochemistry, 40, 1293-1299. http://dx.doi.org/10.1016/j.procbio.2004.05.007

[25] Krowiak, A.W., Szafran, R.G. and Modlski, S. (2011) Biosorption of Heavy Metals from Aqueous Solutions onto Peanut Shell as a Low-Cost Biosorbent. Desalination, 265, 126-134. http://dx.doi.org/10.1016/j.desal.2010.07.042

[26] Langmuir, I. (1916) The Constitution and Fundamental Properties of Solids and Liquids. Journal of American Chemical Society, 38, 2221-2295. http://dx.doi.org/10.1021/ja02268a002

[27] Miretzky, P., Munoz, C. and Chavez, A.C. (2008) Experimental Binding of Lead to a Low Cost Biosorbent: Nopal (Opuntia streptacantha). Bioresource Technology, 99, 1211-1217. http://dx.doi.org/10.1016/j.biortech.2007.02.045

[28] Blazquez, G., Hernainz, F., Calero, M. and Ruiz-Nunez, L.F. (2005) Removal of Cadmium Ions with Olive Stone: The Effect of Some Parameters. Process Biochemistry, 40, 26492655. http://dx.doi.org/10.1016/j.procbio.2004.11.007

[29] Ho, Y.S. and McKay, G. (1999) Pseudo-Second Order Model for Sorption Processes. Process Biochemistry, 34, 451-465. http://dx.doi.org/10.1016/S0032-9592(98)00112-5

[30] Vijayarhavan, K., Palanivelu, K. and Veian, M. (2006) Biosorption of Copper(II) and Cobalt(II) from Aqueous Solutions by Crab Shell Particles. Bioresource Technology, 97, 1411- 
1419. http://dx.doi.org/10.1016/j.biortech.2005.07.001

[31] Li, Q., Zhai, J., Zhang, W., Wang, M. and Zhou, J. (2006) Kinetic Studies of Adsorption of $\mathrm{Pb}(\mathrm{II}), \mathrm{Cr}(\mathrm{II})$ and $\mathrm{Cu}(\mathrm{II})$ from Aqueous Solution by Sawdust and Modified Peanut Husk. Journal of Hazardous Materials, 141, 163-167.

http://dx.doi.org/10.1016/j.jhazmat.2006.06.109

[32] Tiemann, K.J., Gamez, G., Dokken, K., Parsons, J.G. and Gardea-Torresdey, J.L. (2002) Chemical Modification and X-Ray Absorption Studies for Lead(II) Binding by Medicago sativa (Alfalfa) Biomass. Microchemical Journal, 71, 287-293.

http://dx.doi.org/10.1016/S0026-265X(02)00021-8

[33] Wankasi, D., Horsfall, J.M. and Spiff, A.I. (2006) Sorption Kinetics of $\mathrm{Pb}^{2+}$ and $\mathrm{Cu}^{2+}$ Ions from Aqueous Solution by Nipah palm (Nypa fruticans Wurmb) Shoot Biomass. Electronic Journal of Biotechnology, 9, 587-592. http://dx.doi.org/10.2225/vol9-issue5-fulltext-5

[34] Ganji, M.T., Khosravi, M. and Rakhsaee, R. (2005) Biosorption of Pb, Cd, Cu and Zn from Wastewater by Treated Azolla filiculoides with $\mathrm{H}_{2} \mathrm{O}_{2} / \mathrm{MgCl}_{2}$. International Journal of Environmental Science and Technology, 1, 265-271. http://dx.doi.org/10.1007/BF03325841

\section{Submit or recommend next manuscript to SCIRP and we will provide best service} for you:

Accepting pre-submission inquiries through Email, Facebook, LinkedIn, Twitter, etc.

A wide selection of journals (inclusive of 9 subjects, more than 200 journals)

Providing 24-hour high-quality service

User-friendly online submission system

Fair and swift peer-review system

Efficient typesetting and proofreading procedure

Display of the result of downloads and visits, as well as the number of cited articles

Maximum dissemination of your research work

Submit your manuscript at: http://papersubmission.scirp.org/

Or contact aces@scirp.org 